\title{
Plant Growth Mechanisms Using Rhizospheric Bacteria
}

\author{
Sonam Antil* and Rakesh Kumar \\ Department of Microbiology, College of Basic Sciences and Humanities, \\ CCS HAU, Hisar, Haryana 125004, India \\ *Corresponding author
}

\begin{tabular}{l} 
K e y w o r d s \\
$\begin{array}{l}\text { Growth } \\
\text { mechanisms, Plant } \\
\text { growth, } \\
\text { Rhizospheric } \\
\text { bacteria }\end{array}$ \\
Article Info \\
$\begin{array}{l}\text { Accepted: } \\
07 \text { October } 2019 \\
\text { Available Online: } \\
10 \text { November } 2019\end{array}$ \\
\hline
\end{tabular}

Keywords

Growth mechanisms, Plant growth, Rhizospheric bacteria

Accepted:

07 October 2019

10 November 2019

\section{A B S T R A C T}

Soil is rich in microbial diversity comprising of both harmful as well as beneficial microbes. Some of them have deleterious effects on plants whereas some support their host plant by mobilizing nutrients, secreting plant hormones, reducing biotic and abiotic stresses, increasing yield, etc. The microbes which colonize plant roots include bacteria, fungi, algae, protozoa and actinomycetes. Out of these, bacteria are the ones present in abundance. One such group of beneficial bacteria is the plant growthpromoting rhizospheric bacteria (PGPR) that help in supporting plant growth. These bacteria are found near the roots of plants and grow on root exudates. Rhizospheric bacteria which colonize roots not only exert growth-promoting effects but also have positive effects on controlling plant pathogenic microorganisms. This review compiles different mechanisms of growth promotion by PGPR.

\section{Introduction}

The rhizosphere is the area around the roots of a plant where plant- microbial interaction takes place. It is the most prominent zone determined by the root exudates which comprises of various chemical signals, secretion of organic acids, amino acids, sugars and carbon-containing metabolites and due to these root exudates the microbial population present around the roots is different from the surroundings. While rhizospheric bacteria pose neutral effects on plants, they can have some positive as well as negative impacts on their host plant's health and development via complex interactions (Glick, 2012). Some may have deleterious effects and cause disease while some support plant growth by nutrient mobilization, reducing abiotic and biotic stresses, increasing defensive capacity, promoting higher yield etc. (Smith and Smith, 2011). Such bacteria come under the group of plant growth-promoting rhizospheric bacteria (PGPR). Kloepper (1994) describes that the 
plant growth-promoting bacteria are characterized by the following distinct inherent properties: (i) they must have efficiency in root colonization (ii) they should have growth-promoting properties (iii) and they must survive and compete with other microbes till the time needed to express their growth-promoting traits.

\section{Growth promoting traits of PGPR}

PGPR mediated plant growth promotion occurs through alteration of the whole microbial community in the rhizosphere niche by production of various substances (Kloepper and Schroth, 1981). PGPR promote plant growth directly by modulating phytohormone levels, facilitating resource acquisition (phosphorus, nitrogen and essential minerals) or indirectly by decreasing inhibitory effects of pathogens or by acting as biocontrol agents (Glick, 2012).

\section{Direct Mechanisms}

\section{Production of phytohormones}

Production of various phytohormones such as IAA, auxins, cytokinins, ethylene and gibberellins by PGPR is one of the mechanisms by which they enhance plant growth. Among them, IAA is the most common and best-characterized phytohormone, also one of the most physiologically active auxins. The synthesis of phytohormone auxin (Indole-3-acetic acid/ IAA) by microbes has been known for a long time. Root tissues are more sensitive to changing concentration of IAA than other plant tissues (Tanimoto, 2005). IAA affects plant cell division, elongation and differentiation; increases rate of development of root and xylem; stimulates seed and tuber germination; initiates formation of lateral and adventitious roots; affects pigmentation, photosynthesis, responses to light and provides resistance to stressful conditions (Tsavkelova et al., 2006; Spaepen et al., 2007).

Rhizospheric IAA helps in loosening of the plant cell wall as a result of which root exudation increase that supports growth of rhizospheric bacteria by providing additional nutrients (Glick, 2012). It contributes to root and xylem growth, involved in plant cell division, cell elongation and differentiation (Bhardwaj et al., 2014). Bacterial IAA increases root length and surface area and thereby makes the plants accessible to soil nutrients. The production of IAA is a common characteristic of PGPR. The production of IAA helps in detoxifying excess of tryptophan and its analogues that have deleterious effects on bacterial cell as some of the IAA biosynthetic enzymes can convert halogenated and methylated substrates to less toxic compounds (Hutcheson \&Kosuge, 1985; Yamuda et al., 1985; Bar \& Okon, 1992).

\section{Ammonia excretion}

Nitrogen is the most vital nutrient necessary for plant growth and productivity. The atmosphere has about $78 \%$ of nitrogen but is not available to plants. Ammonia is the source of nitrogen which is utilized by plants for their growth. Various reports suggest ammonia production by PGPR as a mechanism of plant growth promotion. Wild strains of $A$. chroococcum excrete ammonia in medium containing $1 \%$ sucrose as a carbon source (Narula et al., 1981; Chandna, 1982). Bacillus licheniformis DS3 has the capacity to produce ammonia along with IAA, $\mathrm{GA}_{3}$ and siderophores (Silpa et al., 2018).

\section{Phosphate solubilization}

Phosphorus $(\mathrm{P})$ is the second most important plant growth-limiting nutrient after nitrogen (Khan et al., 2009). It mostly exists in 
insoluble forms in the soil and the soluble form concentration is very low. Plants are able to absorb only soluble forms of phosphates which are monobasic and diabasic phosphates. To overcome the deficiency of $\mathrm{P}$ in soils, phosphate fertilizers are being applied frequently in agricultural fields. Only a small amount of applied fertilizers is used up by the plants and the rest is converted into insoluble complexes in the soil (McKenzie and Roberts, 1990). The frequent application of phosphate fertilizers is not only costly but also environmentally undesirable. This has led to an option that is eco-friendly and economical to improve crop yields in low $\mathrm{P}$ soils. Microorganisms have the ability to enhance phosphorus availability to plants by mineralizing organic $\mathrm{P}$ in soil and by solubilizing precipitated phosphates (Chen $e t$ al., 2006). The phosphate solubilising bacteria secrete different types of organic acids like carboxylic acid which help in lowering down the $\mathrm{pH}$ of rhizospheric soil and consequently release the bound forms of phosphates like $\mathrm{Ca}_{3}\left(\mathrm{PO}_{4}\right)_{2}$ in calcareous soils. Azotobacter chroococcum and Bacillus sp. have been reported as potent phosphate solubilizers (Kumar et al., 2001; Canbolat et al., 2006).

Besides providing $\mathrm{P}$ to plants, the phosphate solubilizing bacteria help in plant growth by stimulation of biological nitrogen fixation enhancing the availability of other trace elements by synthesizing other plant growthpromoting substances (Suman et al., 2001; Ahmad et al., 2008; Zaidi et al., 2009). Some PGPR help in solubilizing phosphate as a result of which there is an increase in availability of phosphate ions in the soil. Bhattacharyya and Jha (2012) reported some bacterial genera like Bacillus, Azotobacter, Enterobacter, Beijerinckia, Erwinia, Flavobacterium, Microbacterium, Rhizobium, Serratia, Burkholderia and Pseudomonas as the most significant phosphate solubilizing bacteria. Klebsiella strain CPSB4 is an efficient phosphate solubilizer (Gupta et al., 2018).

\section{Indirect mechanisms}

\section{Induced Resistance}

Induced resistance is defined as increased defensive capacity of plants against a broad spectrum of phytopathogens (Ramamoorthy et al., 2001). It is one of the indirect methods by which PGPR promote plant growth. The elevated resistance to plant pathogens occurs due to inducing agents like the attacking pathogens or upon exposure to abiotic and biotic stimuli. Resistance is major of two types- Induced Systemic Resistance (ISR) and Acquired Systemic Resistance (ASR) that occurs when plants activate their defence mechanisms in response to infection by pathogenic agents. ISR-positive plants are in a way 'primed' so that they can react faster and stronger to pathogen attack by inducing defence mechanisms. ISR does not target specific pathogens. Rather it may be effective at controlling diseases caused by different pathogens.

ISR involves jasmonate and ethylene signalling within the plant and these hormones stimulate the host plant's defence responses to a range of pathogens (Verhagen et al., 2004). Saravanakumara et al., (2007) reported induced systemic resistance in tea plants by Pseudomonas fluorescens.

Micromonospora sp. is responsible for strong and quick induction of jasmonate-regulated defence pathway upon exposure to pathogen (Martinez- Hidalgo et al., 2015). Plants acquire enhanced level of resistance to pathogens upon exposure to certain biotic stimuli provided by PGPR which are activated by some molecules and become elicitors. These elicitors are generally salicylic acid, cell wall polysaccharides, phytohormones, 
jasmonic acid, cyclic lipopeptides etc. (Van loon, 2007; Van der Ent et al., 2009; Pe'rezMontano et al., 2014). Kakar et al., (2017) observed induced resistance against blast and sheath diseases in rice, increased plant growth and improved mineral content of rice due to rhizospheric strains of Alcaligenes and Bacillus.

\section{Abiotic stress tolerance}

Abiotic stresses are considered to be the main sources of crop yield reduction. However, the intensity of abiotic stress varies depending on the type of soils (deficiency of hormonal and nutritional imbalances) and plant factors (disease susceptibility, abscission, etc.). Bacteria that have the ability to grow under high salinity conditions will be better able to colonize the roots and external spaces of roots which are themselves exposed to high salinity environment (Marulanda et al., 2010).

PGPR help the plants to combat abiotic stresses, hence promote plant growth. Under abiotic stress conditions, PGPR improves leaf water status especially under drought and salinity stress (Ahmad et al., 2013; Naveed et al., 2014). Klebsiella strain CPSB4 shows significant growth-promoting traits during in vitro studies in broth along with reduction in chromium (VI) (Gupta et al., 2018).

\section{Future perspective}

Plant growth-promoting rhizospheric bacteria promote plant growth in many ways. The productive efficiency can be increased by optimization and acclimatization according to the soil conditions. In future, PGPR as biofertilizers could replace various chemicals applied on crops which directly affect the sustainable agriculture practices. Further research and vast understanding of the mechanisms of PGPR would result in finding more competent strains which may word under harsh agroecological conditions.
The mechanism of action of theplant growthpromoting rhizospheric bacteria can be grouped into two categories - direct effects and indirect effects. Direct effects include growth promotion of plants by modulating phytohormone levels, ammonia excretion, solubilizing insoluble phosphate, plant stress control. On the other hand, PGPR indirectly promotes plant growth by biological control of diseases, antibiosis, inducing systemic resistance etc. Plants acquire resistance to an enhanced level upon exposure to some biotic stimuli received through the plant growthpromoting rhizospheric bacteria.

\section{References}

Ahmad, F., Ahmad, I. and Khan, M.S. (2008) Screening of free-living rhizospheric bacteria for their multiple plant growth promoting activities. Microbiol. Res. 163, 173-181.

Ahmad, M., Zahir, Z.A. and Khalid, M. (2013) Efficacy of Rhizobium and Pseudomonas strains to improve physiology, ionic balance and quality of mung bean under salt-affected conditions on farmer's fields. Plant Physiol. Biochem., 63, 170-176.

Bar, T. \&Okon, Y. (1992) Induction of Indole3-acetic acid synthesis and possible toxicity of tryptophan in Azospirillum brasilense Sp7. Symbiosis, 13, 191198.

Bhardwaj, D., Ansari, M.W., Sahoo, R.K. and Tuteja, N. (2014) Biofertilizers function as key player in sustainable agriculture by improving soil fertility, plant tolerance and crop productivity. Microb. Cell Factories, 13(1), 1-9.

Bhattacharyya, P.N. and Jha, D.K. (2012) Plant growth-promoting rhizobacteria (PGPR): emergence in agriculture. World J. Microbiol. Biotechnol., 28, 1327-1350.

Canbolat, M.Y., Bilen, S.C., Cakmakci, R., Sahin, F. and Aydın, A. (2006) Effect 
of plant growth-promoting bacteria and soil compaction on barley seedling growth, nutrient uptake, soil properties and rhizosphere microflora. Biol. Fertil. Soils, 42, 350-357.

Chandna, S. (1982) Mechanism of ammonia excretion in Azotobacter chroococcum. M.Sc. thesis, Dept. of microbiology, CCSHAU, Hisar.

Chen, Y.P., Rekha, P.D., Arunshen, A.B., Lai, W.A. and Young, C.C (2006) Phosphate solublizing bacteria from subtropical soil and their tricalcium phosphate solublizing abilities. Appl. Soil Ecol., 34, 33-41.

Glick, B.R. (2012) Plant growth-promoting bacteria: mechanisms and applications. Scientifica, 2012, 15.

Gupta, P., Kumar, V., Usmani, Z., Rani, R. and Chandra, A (2018) Phosphate solubilization and chromium (VI) remediation potential of Klebsiella sp. strain CPSB4 isolated from the chromium contaminated agricultural soil. Chemosphere, 192, 318-327.

Hutcheson, S.W. and Kosuge, T. (1985) Regulation of 3-indole acetic acid production in Pseudomonas syringaepv. savastanoi. J. Chem., 260, 6281-6287.

Kakar, K.U., Nawaz, Z., Cui, Z., Almoneafy, A.A., Ullah, R. and Shu, Q.Y. (2017) Rhizosphere-associated Alcaligenes an $\mathrm{d}$ Bacillus strains that induce resistance against blast and sheath blight diseases, enhance plant growth and improve mineral content in rice. J.App.Microbiol., 124,779-796.

Khan, M.S., Zaidi, A., Wani, P.A. and Oves, M. (2009) Role of plant growth promoting rhizobacteria in the remediation of metal contaminated soils. Environ. Chem. Lett., 7, 1-19.

Kloepper, J.W. (1994) Plant growthpromoting rhizobacteria (other systems). Azospirillum/Plant Asso.,
CRC Press, Boca Raton, FL, USA, 111-118.

Kumar, V., Behl, R.K. and Narula, N. (2001) Establishment of phosphate solubilizing strains of Azotobacter chroococcum in the rhizosphere and their effect on wheat cultivars under greenhouse conditions. Microbiol., Res., 156, 87-93.

Mart1'nez-Hidalgo, P., Garc1'a J.M. and Pozo, M.J. (2015) Induced systemic resistance against Botrytis cinerea by Micromonospora strains isolated from root nodules. Front Microbiol, 6, 922.

Marulanda, A., Azcón, R., Chaumont, F., Ruiz-Lozano, J.M. and Aroca, R. (2010) Regulation of plasma membrane aquaporins by inoculation with a Bacillus megaterium strain in maize (Zea mays L.) plants under unstressed and salt-stressed conditions. Planta., 232, 533-543.

McKenzie, R.H. and Roberts, T.L. (1990) Soil and fertilizers phosphorus update. Edmonton, Alberta, 84-104.

Narula, N., Lakshminarayana, K. and Tauro, P. (1981) Ammonia excretion by A. chroococcum. Biotechnol. Bioeng., 23, 467-470.

Naveed, M., Hussain, M.B., Zahir, Z.A., Mitter, B. and Sessitsch, A. (2014) Drought stress amelioration in wheat through inoculation with Burkholderia phytofirmans strain PsJN. Plant Growth Regul., 73, 121-131.

Pe'rez-Montano, F., Alias-Villegas, C., Bellogin, R.A., del Cerro, P., Espuny, M.R., Jimenez-Guerrero, I., LopezBaena, F.J., Ollero, F.J. \&Cubo, T. (2014) Plant growth promotion in cereal and leguminous agricultural important plants: from microorganism capacities to crop production. Microbiol Res., 169, 325-336.

Ramamoorthy, V., Viswanathan, R., Raguchander, T., Prakasam, V. and 
Samiyappan, R. (2001) Induction of systemic resistance by plant growth promoting rhizobacteria in crop against pest and diseases. Crop Prot., 20, 1-11. Saravanakumara, D., Vijayakumarc, C., Kumarb, N. and Samiyappan, R. (2007) PGPR-induced defense responses in the tea plant against blister blight disease. Crop Prot., 26, 556-565.

Silpa, D., Rao, P.B., Kumar, G.K., Ram, M.R. (2018) Plant growth promoting characteristics of Bacillus licheniformis DS3 isolated from agriculture field soil. IJSRST, 4(2).

Smith, S.E. and Smith, F.A. (2011) Roles of arbuscular mycorrhizas in plant nutrition and growth: new paradigms from cellular to ecosystem scales. Annu Rev Plant Biol., 62, 227-250.

Spaepen, S., Vanderleyden, J., Remans, R. (2007) Indole-3-acetic acid in microbial and microorganism plant signaling. FEMS Microbiol. Rev., 31, 425-448.

Suman, A., Shasany, A.K., Singh, M., Shahi, H.N., Gaur, A. and Khanuja, S.P.S. (2001) Molecular assessment of diversity among endophytic diazotrophs isolated from subtropical Indian sugarcane. World J. Microbiol. Biotechnol., 17, 39-45.

Tanimoto, E. (2005) Regulation of root growth by plant hormones- roles for auxin and gibberellins. Critical
Reviews in Plant Sci., 24, 249-265.

Tsavkelova, E.A, Klimova, S.Y., Cherdynsteva, T.A. and Netrusov, A.I. (2006) Microbial producers of plant growth stimulators and their practical use: a review. App. Biochem. Microbiol., 42, 117-126.

Van der Ent, S., Van Wees, S.C.M and Pieterse, C.M.J. (2009) Jasmonate signaling in plant interactions with resistance-inducing beneficial microbes. Phytochem., 70, 1581-1588.

Van Loon, L.C. (2007) Plant responses to plant growth-promoting rhizobacteria. Eur. J. Plant Pathol., 119, 243-254.

Verhagen, B.W.M., Glazebrook, J., Zhu, T., Chang, H.S., Van Loon, L.C. and Pieterse, C.M.J. (2004) The transcriptome of rhizobacteria-induced systemic resistance in Arabidopsis. Mol. Plant-Microbe Interactions, 17, 895-908.

Yamuda,T., Palm, C.J., Brooks, B and Kosuge, T. (1985) Nucleotide sequence of the Pseudomonas savastanoiindole acetic acid show homology with Agrobacterium tumefaciens T-DNA. Proceed. National Acad. Sci., 82, 6522-6526.

Zaidi, A., Khan, M.S., Ahemad, M. \&Oves, M. (2009). Plant growth promotion by phosphate solubilizing bacteria. Acta Microbiol. Immunol. Hung, 56, 263284.

\section{How to cite this article:}

Sonam Antil and Rakesh Kumar. 2019. Plant Growth Mechanisms Using Rhizospheric Bacteria. Int.J.Curr.Microbiol.App.Sci. 8(11): 515-520.

doi: https://doi.org/10.20546/ijcmas.2019.811.063 